\title{
PEMBERDAYAAN MASYARAKAT DESA LEWUR MELALUI PROGRAM SANITASI DAN ANAK NATAS LEWUR
}

\author{
Valeria Suryani Kurnila ${ }^{1}$, Ricardus Jundu ${ }^{2}$, Yohanes Kurniawan ${ }^{3}$, \\ ${ }^{1}$ STKIP Santu Paulus. Email: valeria.suryani@gmail.com \\ ${ }^{2}$ STKIP Santu Paulus. Email: rickyjundu@gmail.com \\ ${ }^{1}$ STKIP Santu Paulus. Email: yohaneskurniawan91@gmail.com
}

\begin{abstract}
Higher Education must conduct community service. Community service is a variety of activities by sociocultural conditions of society. One of the villages targeted for the service is the village of Lewur. The village is one of the communities located in West Manggarai Regency. Villagers of Lewur mostly have livelihoods as farmers, because Lewur found in areas of hills and valleys and high rainfall, with sufficient agricultural land area, so it is potential to continue to develop. The devotion activities undertaken are the Sanitasi and the Natas Lewur Children program. Sanitation program is carried out in the form of cleaning the village area around the neighbourhood of the garden and residents' houses and roads around the village. The Natas Lewur Children Program implemented in the form of unique guidance for children, based on local natural and cultural resources. This activity is in the way of tutoring and Scouting, designed in the style of games. Also, the the Natas Lewur Children program organised activities for teachers in the village, by conducting mathematical software training. Based on the evaluation results, this program can increase public awareness about hygiene as well as the importance of education. Indicators of program success are the cleaner village environment and the continuous running of the Natas Lewur Children group run by teachers and youths in the village.
\end{abstract}

Keywords: Sanitation Program, Natas Lewur Children.

\begin{abstract}
ABSTRAK
Perguruan Tinggi wajib menyelenggarakan pengabdian masyarakat. Pengabdian masyarakat merupakan berbagai bentuk kegiatan sesuai dengan kondisi sosial budaya masyarakat. Salah satu desa yang menjadi sasaran pelaksanaan pengabdian adalah desa Lewur. Desa tersebut adalah salah satu desa yang terletak di Kabupaten Manggarai Barat. Penduduk desa Lewur sebagian besar memiliki mata pencaharian sebagai petani, karena berada di wilayah yang perbukitan dan lembah serta curah hujan yang cukup tinggi, dengan luas areal pertanian cukup, sehingga sangat berpotensi untuk terus dikembangkan. Kegiatan pengabdian yang dilakukan adalah program Sanitasi dan Anak Natas Lewur. Program Sanitasi yang dilakukan berupa pembersihan wilayah desa di sekitar lingkungan kebun dan rumah warga serta jalan raya di sekitar desa tersebut. Program Anak Natas Lewur yang dilaksanakan berupa bimbingan khusus bagi anak-anak, yang berbasis kekayaan alam dan budaya setempat. Kegiatan ini berupa bimbingan belajar dan Pramuka, yang dirancang dalam bentuk permainan. Selain itu, Program Anak Natas lewur mengadakan kegiatan bagi para guru di desa tersebut, dengan mengadakan pelatihan software matematika. Berdasarkan hasil evaluasi, program ini dapat meningkatkan kesadaran masyarakat tentang kebersihan serta pentingnya pendidikan. Indikator keberhasilan program adalah, lingkungan desa yang semakin bersih, dan tetap berjalannya kelompok Anak Natas Lewur yang dikelola oleh guru dan para pemuda di desa tersebut.
\end{abstract}

Kata Kunci: Program Sanitasi, Anak Natas Lewur.

\section{PENDAHULUAN}

Kuliah Kerja Nyata merupakan suatu kegiatan yang melibatkan dosen dan mahasiswa untuk mengabdi kepada masyarakat. Kegiatan ini adalah kegiatan yang 
berorientasi pada kepentingan dan pemberdayaan masyarakat. Masyarakat adalah kelompok majemuk dengan tingkat pendidikan yang berbeda-beda serta memiliki beragam watak, ciri, aktivitas yang berbeda pula. Terjun ke masyarakat bagi para mahasiswa merupakan tingkat pembelajaran yang sangat berharga dan kreatif untuk mengaplikasikan/menerapkan pengetahuan yang telah dipelajari di bangku kuliah di perguruan tinggi. Hal ini dikarenakan bahwa pada dasarnya mahasiswa datang dari masyarakat dan akan kembali ke masyarakat baik setelah menyelesaikan proses pendidikan maupun terutama dalam tahap proses. Sehingga diharapkan nantinya mampu menjadi pribadi berkualitas dan dapat mewujudkan berbagai kegiatan yang berorientasi kepada masyarakat sebagai bentuk pengabdian kepada masyarakat yang merupakan salah satu darma perguruan tinggi. Undang-undang nomor 12 tahun 2012 tentang Pendidikan Tinggi menegaskan bahwa kewajiban perguruan Tinggi adalah menyelenggarakan pendidikan, penelitian dan pengabdian masyarakat. Undang-undang tersebut juga menegaskan bahwa pengabdian kepada masyarakat adalah kegiatan sivitas akademika yang memanfaatkan Ilmu Pengetahuan dan Teknologi untuk memajukan kesejahteraan masyarakat dan mencerdaskan kehidupan bangsa.

Pada saat terjun kelapangan ini juga merupakan ajang yang sangat potensial bagi dosen dan para mahasiswa untuk mengasah kepekaan serta kepedulian terhadap situasi dan kondisi lingkungan sekitar. Dalam pelaksanaan kegiatan ini dosen dan mahasiswa dituntut untuk memiliki kemampuan beradaptasi, bergaul dan berbaur dengan masyarakat sehingga mampu memahami setiap situasi yang berkembang di masyarakat dan memberikan kontribusi bagi masyarakat. Kegiatan yang dilakukan dalam berbagai bentuk kegiatan sesuai dengan budaya akademik, keahlian, dan/atau otonomi keilmuan Sivitas Akademika serta kondisi sosial budaya masyarakat (Undang-undang nomor 12 tahun 2012).

Salah satu desa yang menjadi sasaran pelaksanaan pengabdian adalah desa Lewur. Desa tersebut adalah salah satu desa yang terletak di Kabupaten Manggarai Barat. Penduduk desa Lewur sebagian besar memiliki mata pencaharian sebagai Petani, berada di wilayah yang perbukitan dan lembah serta curah hujan yang cukup tinggi, dengan luas areal pertanian cukup, sehingga sangat berpotensi untuk terus dikembangkan. Desa Lewur dengan kondisi iklim, tanah yang subur dan lahan yang cukup luas sangat berpotensi untuk sektor peternakan sehingga usaha pemeliharaan ternak juga digeluti oleh masyarakat sebagian masyarakat, sebagai alternatif. Hewan peliharaan, seperti kerbau, sapi, kuda, bebek, ayam, anjing, babi dan kambing, sangat potensial dipelihara oleh warga masyarakat, karena cara dan proses pemeliharaannya yang mudah, juga jenis makanannya tidak sulit didapatkan oleh masyarakat (ketersediaan pakan sangat cukup:, seperti. Cateria, rumput Raja, Pisang, lemtoro dan lain-lain). Namun kondisi tersebut tidak didukung oleh kesadaran kebersihan yang cukup dimiliki masyarakat. Sehingga lingkungan kurang terasa nyaman. Selain itu, berdasarkan masukan dari aparat desa dan masyarakat, desa Lewur perlu juga dibenahi dalam bidang pendidikan. Hal ini dimaksudkan agar anak, guru maupun siswa memilki wawasan lebih terkait dengan proses pembelajaran, kegiatan ekstra maupun pemanfaatan teknologi. Pembenahan ini diharapkan bisa meningkatkan kesadaran masyarakat akan pentingnya 
pendidikan dan adanya pembaharuan strategi masyarakat dalam membina anak dalam lingkungan rumah, sekolah maupun sekitarnya.

Tim Dosen dan mahasiswa melakukan kegiatan berupa program Sanitasi dan Anak Natas Lewur. Program Sanitasi diawali dengan pelacakan jumlah ternak di setiap rumah, kemudian dilakukan program Sanitasi Total Berbasis Masyarakat. Pasal 1 Peraturan Menteri Kesehatan nomor 3 tahun 2014 menyatakan bahwa Sanitasi Total Berbasis Masyarakat yang selanjutnya disingkat STBM adalah pendekatan untuk mengubah perilaku higienis dan saniter melalui pemberdayaan masyarakat dengan cara pemicuan. Kegiatan Sanitasi yang dilakukan adalah pengolahan kotoran ternak dan kotoran organik menjadi pupuk kompos yang dimanfaatkan bagi tanaman yang dimiliki masyarakat. Selain itu, untuk meningkatkan kesadaran masyarakat akan kebersihan, dilakukan pembersihan di wilayah desa dan menyiapkan tempat sampah organik dan non organik secara terpisah. Kegiatan ini merupakan kegiatan yang juga mendukung kegiatan pemerintah. Selain itu, kegiatan yang dilakukan adalah pemberdayaan anakanak Desa Lewur melalui kegiatan Anak Natas Lewur. Kegiatan tersebut berupa bimbingan khusus bagi anak-anak, yang berbasis kekayaan alam dan budaya setempat. Kegiatan ini berupa bimbingan belajar dan Pramuka, yang dirancang dalam bentuk permainan. Permainan adalah sebuah kontes yang menyebabkan para pemain saling berinteraksi dan belajar untuk bertanggung jawab, tenggang rasa dan mandiri (Munadi, 2008). Permainan juga adalah suatu aktivitas untuk mendapatkan ide-ide, pengetahuan atau keterampilan siswa serta berguna untuk membentuk poin-poin dramatis yang jarang siswa lupakan (Silberman, 2005). Permainan memiliki beberapa keunggulan antara lain 1) meningkatkan kesehatan fisik dan mental; 2) meningkatkan perkembangan kognitif; 3) meningkatkan kemampuan berbahasa dan menulis; dan 4) meningkatkan kompetensi sosial (Stegelin, 2007). Sehingga, kegiatan tersebut dapat berjalan dengan baik dan anak-anak lebih tertarik untuk mengikuti kegiatan tersebut. Tempat pelaksanaannya adalah Mbaru Gendang yang merupakan rumah adat masyarakat setempat serta sekolah yang berdekatan dengan rumah adat tersebut. Pemilihan tempat tersebut sebagai sarana bagi siswa untuk mengenal budaya lebih dalam dan tetap merasakan suasana belajar yang mereka alami di sekolah. Kegiatan Anak Natas Lewur tidak hanya ditujukan bagi anak, namun dimanfaatkan juga oleh para guru yang ada di desa tersebut. Para guru diberi pelatihan penggunaan software matematika yang bisa mereka manfaatkan dalam pembelajaran di sekolah.

\section{METODE PELAKSANAAN}

Program Sanitasi dan Anak Mbaru Gendang, dilakukan melalui beberapa tahap. Hal ini sangat diperhatikan agar manfaatnya bisa dinikmati oleh masyarakat Desa Lewur. Tahap-tahap kegiatan tersebut adalah sebagai berikut:

\section{Observasi dan Perencanaan}

Observasi dilakukan oleh Tim Dosen untuk mengetahui masalah dan solusi yang tepat bagi masyarakat Desa Lewur. Kegiatan ini dilakukan selama 3 hari dengan melibatkan aparat Desa Lewur. Selain itu, Tim Dosen juga melakukan wawancara dengan beberapa beberapa masyarakat dan guru di desa tersebut. Setelah melakukan 
hal-hal tersebut, maka Tim Dosen dan Aparat Desa membuat kesepakatan untuk menghadirkan mahasiswa di desa tersebut, dalam rangka membantu pemberdayaan masyarakat Desa Lewur. STKIP Santu Paulus Ruteng merupakan Sekolah tinggi yang memiliki 6 program studi, yaitu Pendidikan Teologi, Pendidikan Bahasa Inggris, pendidikan Guru Sekolah Dasar (PGSD), Pendidikan Matematika, PAUD dan Pendidikan Bahasa Indonesia. Mahasiswa yang terlibat dalam kegiatan pengabdian ini sebanyak 20 orang dari 6 program studi tersebut. Sehingga kegiatan yang dilakukan merupakan hasil kolaborasi yang bermanfaat di desa Lewur. Dosen yang terlibat adalah dosen program Studi Pendidikan Matematika yang memiliki bidang kelimuan Matematika, Kimia dan Fisika.

\section{Tindakan}

Setelah melakukan kegiatan observasi dan diskusi bersama aparat dan warga desa, maka selanjutnya Tim Dosen dan Mahasiswa melakukan kegiatan berupa program SANITASI dan Anak Natas Lewur. Program Sanitasi yang dilakukan berupa pembersihan wilayah desa di sekitar lingkungan kebun dan rumah warga serta jalan raya di sekitar desa tersebut. Program Anak Natas Lewur yang dilaksanakan berupa bimbingan khusus bagi anak-anak, yang berbasis kekayaan alam dan budaya setempat. Kegiatan ini berupa bimbingan belajar dan Pramuka, yang dirancang dalam bentuk permainan. Selain itu, kegiatan Anak Natas lewur juga diperuntukkan bagi para guru di desa tersebut, dengan melibatkan mereka dalam pelatihan software matematika.

\section{Evaluasi}

Setelah melakukan tindakan, selanjutnya dilakukan evaluasi terhadap kegiatan yang telah dilakukan. Hal ini dibuat untuk mendapatkan informasi keterlaksanaan serta hal-hal yang perlu dilakukan untuk selanjutnya.

\section{HASIL DAN PEMBAHASAN}

Desa Lewur, kecamatan Kuwus Kabupaten Manggarai Barat menjadi salah satu tempat pelaksanaan kegiatan Pengabdian Masyarakat. Pelaksanaan KKN terhitung sejak tanggal 17 Juli 2017 hingga 19 Agustus 2017. Kegiatan pertama yang dilakukan adalah Tim Pengabdian menawarkan beberapa program kegiatan yang akan dilaksanakan di desa Lewur tanpa menutupi berbagai kegiatan yang akan direncanakan oleh desa.

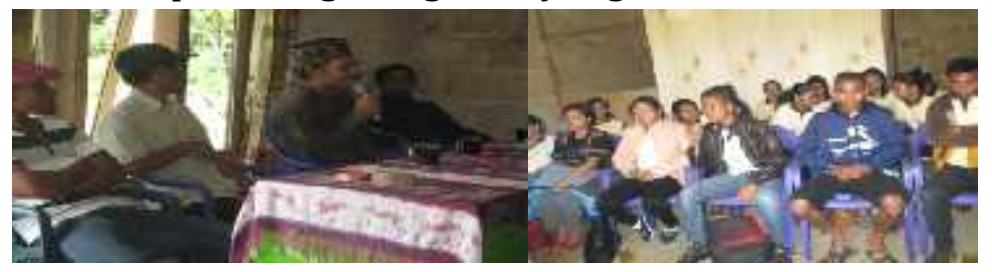

Gambar 1 Diskusi Program kerja Sanitasi

Kegiatan pertama yang dilakukan tim dosen dan mahasiswa adalah membantu Dinas Kesehatan untuk mendata rumah sehat atau yang disebut dengan Sanitasi Total Berbasis Masyarakat (STBM). Kegiatan ini bertujuan untuk mengetahui situasi dan kesehatan masyarakat. 


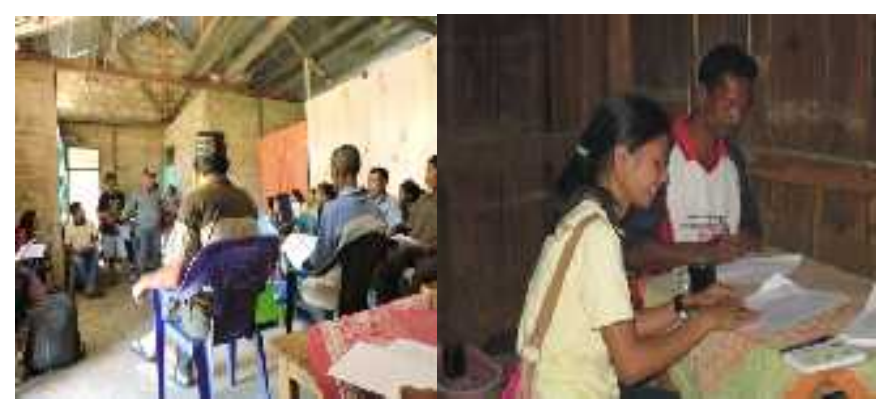

Gambar 2 Kegiatan STBM

Tim tersebut juga membantu petugas dari Dinas Peternakan untuk mendata ternak di setiap kepala keluarga. Kegiatan ini bertujuan untuk mengetahui kapasitas ternak di setiap kepala keluarga serta mengetahui cara perawatan ternak dan pemanfaatan kotoran ternak.

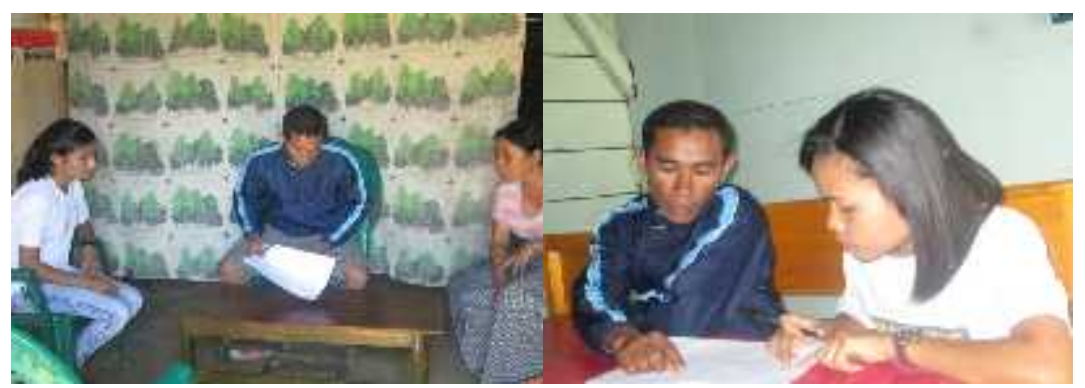

Gambar 3 Pendataan ternak warga

Berdasarkan hasil observasi tersebut, maka selanjutnya tim dosen dan mahasiswa mulai melakukan berbagai kegiatan sanitasi di masyarakat. Tim dosen dan mahasiswa mulai melaksanakan kegiatan pertama dengan memanfaatkan pupuk kompos sebagai hasil pembersihan lingkungan rumah dan kebun bersama para warga. Hasil pembersihan tersebut menghasilkan pupuk kompos yang cukup banyak, yang berasal dari ternak masyarakat di sekitar. Pupuk kompos tersebut digunakan untuk menanam sayur-sayuran di pekarangan warga desa. Penanaman sayur tersebut dibantu oleh para mahasiswa.

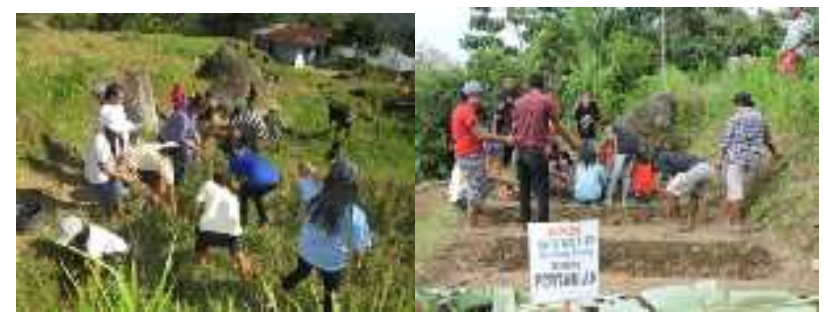

Gambar 4 Penanaman sayur-sayuran

Tim Dosen dan mahasiswa juga melakukan bakti sosial-pembersihan lingkungan masyarakat dengan membersihkan jalan raya dan got di sekitar lingkungan warga. Hal ini bertujuan agar terciptanya lingkungan yang bersih dan sehat.

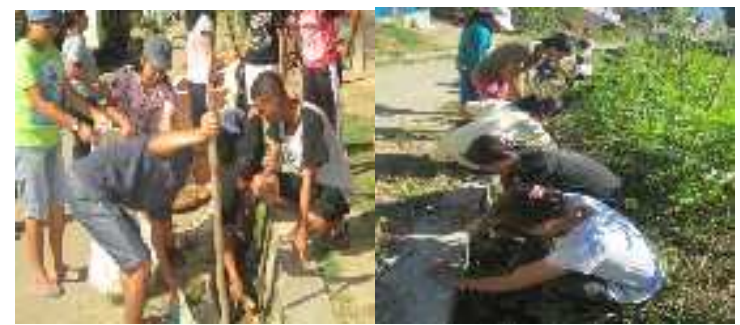

Gambar 5 Pembersihan lingkungan warga 
Untuk menjamin lingkungan desa tetap bersih, maka selanjutnya Tim tersebut melakukan pembuatan tempat sampah dengan memanfaatkan bahan-bahan lokal (bilahan bambu) yang akan digunakan untuk menampung sampah-sampah di lingkungan masyarakat. Tempat sampah tersebut dimanfaatkan untuk menampung sampah-sampah organik dan sampah-sampah non organik secara terpisah. Sehingga, masyarakat bisa memanfaatkan sampah organik untuk pembuatan pupuk.

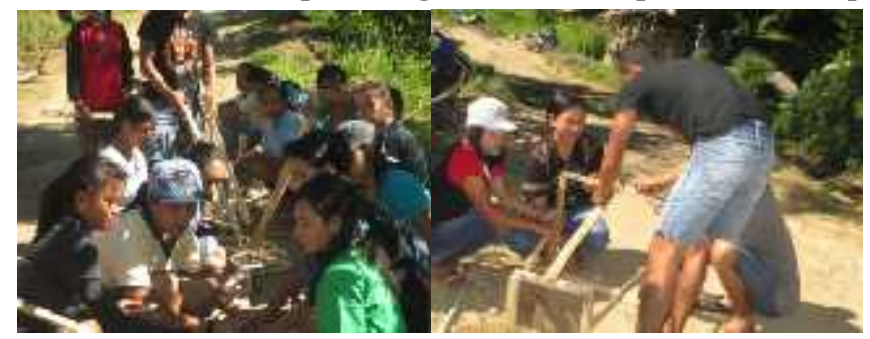

Gambar 6 Pembuatan tempat Sampah

Kemudian Tim melakukan diskusi bersama warga untuk melakukan berbagai kegiatan yang berkaitan dengan peningkatan bidang pendidikan di desa Lewur. Warga dan Tim menyepakati bahwa kegiatan dilakukan atau terpusat di Mbaru Gendang sebagai rumah adat di desa tersebut, serta salah satu sekolah yang letaknya mudah dijangkau oleh siswa, guru atau masyarakat Lewur. Rancangan kegiatan yang dibuat juga bermacam-macam, yaitu Bimbingan Belajar, Pramuka, dan Pelatihan Software bagi guru.

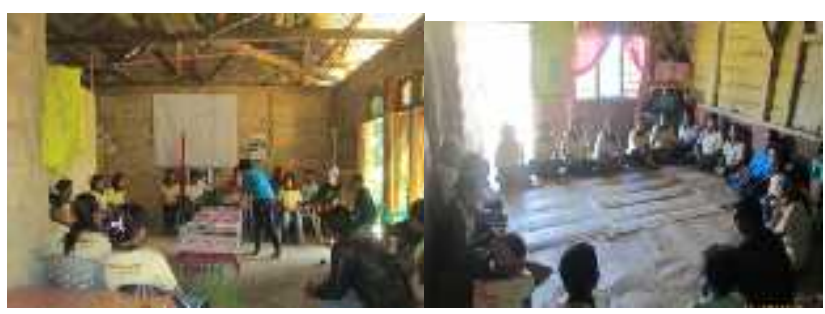

Gambar 7 Diskusi program Anak Natas Lewur

Hal ini mendapat respon yang sangat positif dari pihak sekolah dimana mereka langsung melimpahkan kesempatan kepada mahasiswa untuk melakukan kegiatan tersebut, Bahkan, pihak sekolah menyiapkan waktu khusus di sore hari untuk pelaksanaan kegiatan-kegiatan yang telah di dan selanjutnya pihak sekolah menetapkan waktu khusus untuk kegiatan-kegiatan yang telah direncanakan. Kegiatan pertama yang dilakukan adalah memberikan bimbingan sore hari bagi anak-anak di sekitar desa Lewur dengan memanfaatkan ruangan sekolah yang ada di SDK Lewur. Bimbingan yang diberikan berupa percobaan IPA sederhana serta permainan-permainan matematika bagi anak-anak. Salah satu permainan matematika dikemas dalam bentuk permainan ular tangga bernuansa budaya Manggarai. Pemilihan gambar-gambar yang digunakan pada media ini sangat memperhatikan aspek budaya. Gambar-gambar tersebut dibuat sedemikian rupa, dengan tetap memperhatikan aspek-aspek penempatan yang sesuai dengan situasi, kondisi atau tempat. Misalnya, gambar yang ditampilkan adalah rumah gendang yang berfungsi sebagai bengkel pada permainan ini. Oleh karena itu, buklet permainan yang dirancang sebagai alat bantu pada bengkel, dirancang dengan mencantumkan juga gambar-gambar berupa gendang, gong, roto, loce, tange dan beberapa benda yang biasanya terdapat di rumah gendang. Hal ini dirancang agar siswa 
juga memiliki pengetahuan budaya, selain memahami konsep matematika. Selain itu, pertanyaan-pertanyaan pada permainan ular tangga dirancang juga menggunakan istilah-istilah budaya, cerita-cerita rakyat atau makanan khas Manggarai.

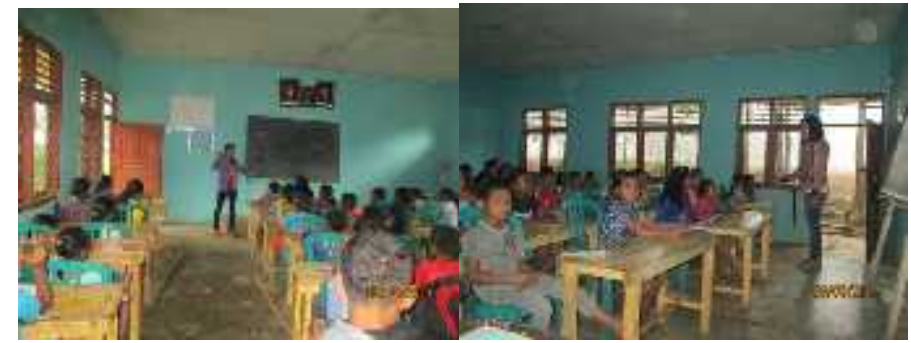

Gambar 8 Percobaan IPA dan Permainan Matematika

Selain kegiatan percobaan IPA dan permainan matematika, tim dosen dan mahasiswa juga melakukan kegiatan Pramuka bersama siswa SDK Lewur. Kegiatan ini bertujuan melatih para siswa untuk bersikap disiplin, bertanggung jawab dan menumbuhkan rasa persatuan dan rasa semangat kebangsaan dan patriotisme. Kegiatan ini sebagai bentuk penerapan kegiatan pramuka yang melibatkan anak-anak di desa Lewur. Anak-anak terlihat antusias dengan diberikan latihan PBB, berbagai macam permainan untuk meningkatkan ketangkasan.

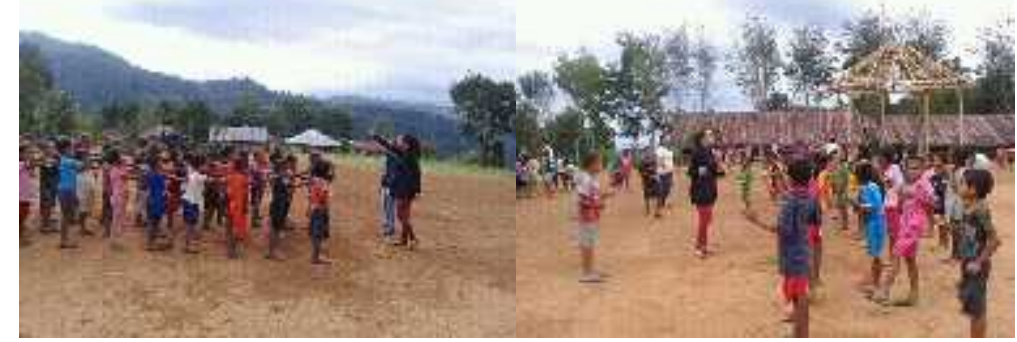

Gambar 9 Berbagai macam permainan untuk meningkatkan ketangkasan

Antusias ternyata tidak hanya berasal dari para siswa, namun juga dari para guru. Tim dosen dan mahasiswa juga diminta untuk memberikan pelatihan software matematika bagi para guru. Pelatihan software matematika untuk guru matematika dengan tujuan untuk membantu guru dalam memperlancar dan memperluas wawasannya dalam bidang matematika. Software yang mereka pelajari adalah Geogebra dan algebrator.

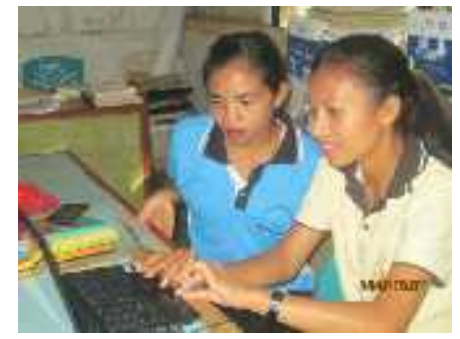

Gambar 10. Pelatihan Sofware Matematika bagi Guru

\section{SIMPULAN}

Kegiatan ini telah dilaksanakan dengan baik. Masyarakat di Desa Lewur merasakan banyak manfaat melalui kegiatan tersebut. Kebersihan di desa tersebut semakin meningkat. Masyarakat pun memanfaatkan sampah-sampah yang ditampung untuk pembuatan pupuk kompos. Pupuk tersebut digunakan untuk tanaman sayur-sayuran 
yang ada di pekarangan rumah. Selain itu, kelompok bimbingan tetap dilanjutkan oleh warga desa, dengan melibatkan guru para pemuda di desa tersebut. Anak-anak di desa tersebut, tetap memiliki aktivitas untuk mempelajari banyak hal-hal baru, baik yang terkait dengan pelajaran di sekolah maupun di luar hal tersebut. Anak-anak juga memiliki pengetahuan mengenai budaya dan keterkaitannya dengan mata pelajaran lain yang dia pelajari di sekolah. Guru-guru di desa tersebut juga mulai memanfaatkan teknologi terbaru berupa pemanfaatan software dalam pembelajaran di sekolah. Berdasarkan hasil-hasil tersebut, kegiatan seperti ini harus tetap dilaksanakan dan memberikan pengarahan bagi aparat desa untuk memanfaatkan potensi alam di desa serta membuka Taman Bermain Bagi Anak. Taman Bermain tersebut dikelola oleh aparat desa dengan melibatkan sekolah-sekolah yang ada di desa tersebut.

\section{UCAPAN TERIMA KASIH}

Ucapan terima kasih disampaikan kepada lembaga STKIP Santu Paulus Ruteng yang telah mendukung kegiatan ini dilaksanakan dengan baik, melalui hibah pengabdian. Ucapan terima kasih juga kepada para mahasiswa, aparat desa Lewur, serta para guru di desa tersebut, yang telah melibatkan diri dalam pelaksanaan pengabdian ini.

\section{DAFTAR RUJUKAN}

Munadi, Y. (2008). Media pembelajaran. Gaung Persada Press, 163-165.

Peraturan Menteri Kesehatan nomor 3 tahun 2014. (2014). Sanitasi Total Berbasis Masyarakat. Pasal 1, halaman 9.

Silberman, M. (2005). Active learning. (Terjemahan Sarjuli et.al). Pustaka Insan Madani, 21-22

Stegelin, D. A. (2007). Making the case for play policy. McGraw-Hill. 104-105

Undang-undang nomor 12 tahun 2012. (2012). Pendidikan Tinggi. Bagian Kesebelas (Pengabdian Kepada Masyarakat), Pasal 47. 